\title{
EXPERIMENTAL AND THEORETICAL INVESTIGATION OF AN INNOVATIVE EVAPORATIVE CONDENSER FOR RESIDENTIAL REFRIGERATOR
}

\author{
M.M. Nasr and M. Salah Hassan \\ Department of Mechanical Power Engineering; Faculty of \\ Engineering, Minia University, Egypt \\ nasr17@yahoo.com; salahkun@hotmail.com
}

(Received April 20, 2008 Accepted June 19, 2008)

In this study, an innovative, evaporative condenser for residential refrigerator was introduced. A vapor compression cycle incorporating the proposed evaporative condenser was tested to evaluate the cycle performance. To allow for evaporative cooling, sheets of cloth were wrapped around condenser to suck the water from a water basin by capillary effect. The thermal properties at the different points of the refrigeration cycle were measured for typical operating conditions. The experimental results showed that the condenser temperature increases $0.45{ }^{\circ} \mathrm{C}$ for each degree increase in evaporator temperature when the air velocity $2.5 \mathrm{~m} / \mathrm{s}$, and the ambient conditions is $29{ }^{\circ} \mathrm{C}$ and the relative humidity is $37.5 \%$, Meanwhile, the condenser temperature increase is $0.88{ }^{\circ} \mathrm{C}$ in the case of air velocity $1.1 \mathrm{~m} / \mathrm{s}$ and ambient conditions of $31^{\circ} \mathrm{C}$ and relative humidity of $47.1 \%$. A theoretical model for the evaporative condenser was developed, and validated by experimental results. The theoretical model showed that the evaporative condenser can operate at a condensing temperature $20 \mathrm{C}$ lower than that of the air cooled condenser for an average heat flux of $150 \mathrm{~W} / \mathrm{m}^{2}$, and at air velocity $3 \mathrm{~m} / \mathrm{s}$. The effect of the different parameters on the condenser temperature was studied too.

KEYWORDS: evaporative cooling, condenser, refrigeration

\section{INTRODUCTION}

Decreasing energy consumption by renewable energy is an important task for decreasing global warming. Residential vapor compression units are widely spread all over the world. Any trials to decrease the energy consumption of these units will decrease the dependence on fossil fuel. The energy consumption of these units depends on the COP, which is improved by decreasing the condensing temperature. There are three types of condensers of refrigerating systems: air-cooled, water-cooled, and evaporative-cooled. The COP of the refrigerating systems with air cooled condenser drops down when the ambient air temperature increases especially in hot regions in summer. The condensers of residential refrigerators and air conditioners are mainly air cooled. Meanwhile, evaporative cooled condensers are widely used in large units. Many researches were done to investigate the evaporative condenser of large units [1,2] . Little attention was given to the application of evaporative condensers for small residential refrigerating systems. 


\section{NOMENCLATURE}

\begin{tabular}{|c|c|c|c|}
\hline $\begin{array}{l}\mathrm{A} \\
\mathrm{A}_{0}\end{array}$ & $\begin{array}{l}\text { total area, } \mathrm{m}^{2} \\
\text { orifice area, } \mathrm{m}^{2}\end{array}$ & $\mathrm{Y}$ & specific humidity, $\mathrm{kg}_{\mathrm{v}} / \mathrm{kg}_{\mathrm{a}}$ \\
\hline $\mathrm{a}$ & outer surface area per unit & \multicolumn{2}{|c|}{ GREEK LETTERS } \\
\hline & length, $\mathrm{m}^{2}$ & $\Delta \mathrm{T}$ & temperature difference between \\
\hline $\mathrm{COP}$ & coefficient of performance & & condensate and inner wall \\
\hline C,Cp & specific heat, J/kg. K & $\Delta \mathrm{x}$ & incremental length , m \\
\hline $\mathrm{D}$ & diameter, m & $\delta$ & thickness, m \\
\hline G & mass velocity, $\mathrm{kg} / \mathrm{m}^{2} \mathrm{~s}$ & $\lambda$ & thermal conductivity, W/m K \\
\hline g & gravitational acceleration, $\mathrm{m} / \mathrm{s}^{2}$ & $\mu$ & dynamic vescosity, kg/m s \\
\hline $\mathrm{H}$ & $\begin{array}{l}\text { height, } \mathrm{m} \\
\text { heat transfer coefficient } \mathrm{W} / \mathrm{m}^{2} \mathrm{~K}\end{array}$ & $\rho$ & density, $\mathrm{kg} / \mathrm{m}^{3}$ \\
\hline $\mathrm{h}_{\mathrm{fg}}$ & latent heat of vaporization, $\mathrm{J} / \mathrm{kg}$ & \multicolumn{2}{|c|}{ SUBSCRIPTS } \\
\hline i & enthalpy, J/kg & & air amb \\
\hline $\mathrm{K}$ & flow coefficient & $b$ & basin \\
\hline $\mathrm{k}_{\mathrm{m}}$ & mass transfer coefficient $\mathrm{kg} / \mathrm{m}^{2} \mathrm{~s}$ & c & condenser or condensing \\
\hline $\mathrm{L}$ & length, m & & refrigerant compressor \\
\hline Le & Lewis number & d & duct or dry \\
\hline $\mathrm{m}$ & mass flow rate, $\mathrm{kg} / \mathrm{s}$ & dw & duct wall \\
\hline $\mathrm{Nu}$ & Nusselt number & e & evaporator \\
\hline $\mathrm{n}$ & number of condenser tubes & eq & equivalent \\
\hline $\mathrm{P}$ & pitch, m & $\mathrm{f}$ & felt (cloth) \\
\hline $\mathrm{p}$ & pressure, $\mathrm{N} / \mathrm{m}^{2}$ & $\mathrm{i}$ & inner of tube or inlet \\
\hline $\operatorname{Pr}$ & Prandtle number & in & insulation \\
\hline Q & heat, W & 1 & liquid water \\
\hline q & heat transfer rate, $\mathrm{W} / \mathrm{m}^{2}$ & $\operatorname{lr}$ & liquid refrigerant \\
\hline $\operatorname{Re}$ & Reynolds number & $\mathrm{m}$ & mixture \\
\hline RH & relative humidity & 0 & outer or outlet \\
\hline 1 & radius, $\mathrm{m}$ & $\mathrm{r}$ & refrigerant \\
\hline $\mathrm{T}$ & temperature, ${ }^{\circ} \mathrm{C}$ & $\mathrm{s}$ & sensible \\
\hline $\mathrm{U}$ & overall heat transfer coefficient, & & tube \\
\hline & $\mathrm{W} / \mathrm{m}^{2} \mathrm{~K}$ & & water vapor \\
\hline V & specinic volume, m /kg & $\mathrm{vr}$ & vapor refrigerant \\
\hline $\mathrm{V}$ & velocity, m/s & W & water \\
\hline W & width, m & & \\
\hline $\mathrm{w}_{\mathrm{C}}$ & compressor specific work, kJ/kg & SUI & RSCRIPTS \\
\hline & coordinate in direction of air & * & saturated air \\
\hline
\end{tabular}

Goswami et al. [3], and Hajidavallo [4] studied small size air conditioning system with evaporative condensers. They evaporatively cooled the condenser air by flowing it through the wetted media pads before entering condenser. Their results showed $10-20 \%$ saving in electrical energy. Hwang et al. [5] studied the performance of an 
innovative evaporative condenser and compared it with that of a conventional air-cooled condenser for a split heat pump system. In their design, the condenser tubes are immersed in a water bath. Disks, which are partially submerged in the water bath, are rotated by a motor while air is blown across them. The disks carry a thin water film from the bath to the air system, and water from the film is evaporated into the air stream. The condenser tubes reject heat to the water bath and the evaporation from the film rejects heat to the air stream. Their experimental results showed that the evaporative condenser has a higher capacity than the air-cooled condenser by 1.8 to $8.1 \%$, a higher COP by 11.1 to $21.6 \%$.

In this work an experimental and theoretical investigation was performed to evaluate the application of evaporative condenser in residential refrigerator. The condenser design is a modification for the simple air cooled condenser of residential refrigerator. It doesn't need any design modifications. It is a copper serpentine laid longitudinally on a basin having a shallow layer of water. Thin sheets of cloth were immersed in the water and wrapped over each tube of the serpentine. These components were inserted inside a rectangular duct. The sheets suck the water, by capillary suction, from the basin and wet the tubes. Air is forced through the duct. The condenser rejects heat to the air by evaporation of some water from cloth sheets surrounding the tubes, and the air is cooled evaporatively by the basin water and the vertical strips of cloth.

\section{2- SYSTEM DESIGN AND EXPERIMENTAL SET-UP}

The layout of the tested refrigeration cycle is shown in Fig. 1. The main components are hermetically sealed compressor 250-W, the proposed evaporative condenser, capillary tube expansion valve, and U-shape aluminum plate evaporator immersed in water inside insulated tank. The evaporator load is controlled by flowing the water through the tank.

The details of the condenser, are shown in Fig 2, and table 1. The condenser is a copper serpentine laid longitudinally on a basin with a shallow layer of water. A thin sheet of cloth was immersed in the water from one side and wrapped over each tube of serpentine from the other side. These components were inserted inside a rectangular duct. The cloth sheets suck the water from the basin and wet the tubes. A centrifugal blower was used to deliver air through the condenser duct. A divergent duct and guide vanes were installed between the blower and the condenser test section to ensure uniform flow distribution.

The condenser rejects heat to the air by evaporation of some water from the cloth sheets surrounding the tubes, and the air is evaporatively cooled by the basin water and the vertical cloth. 


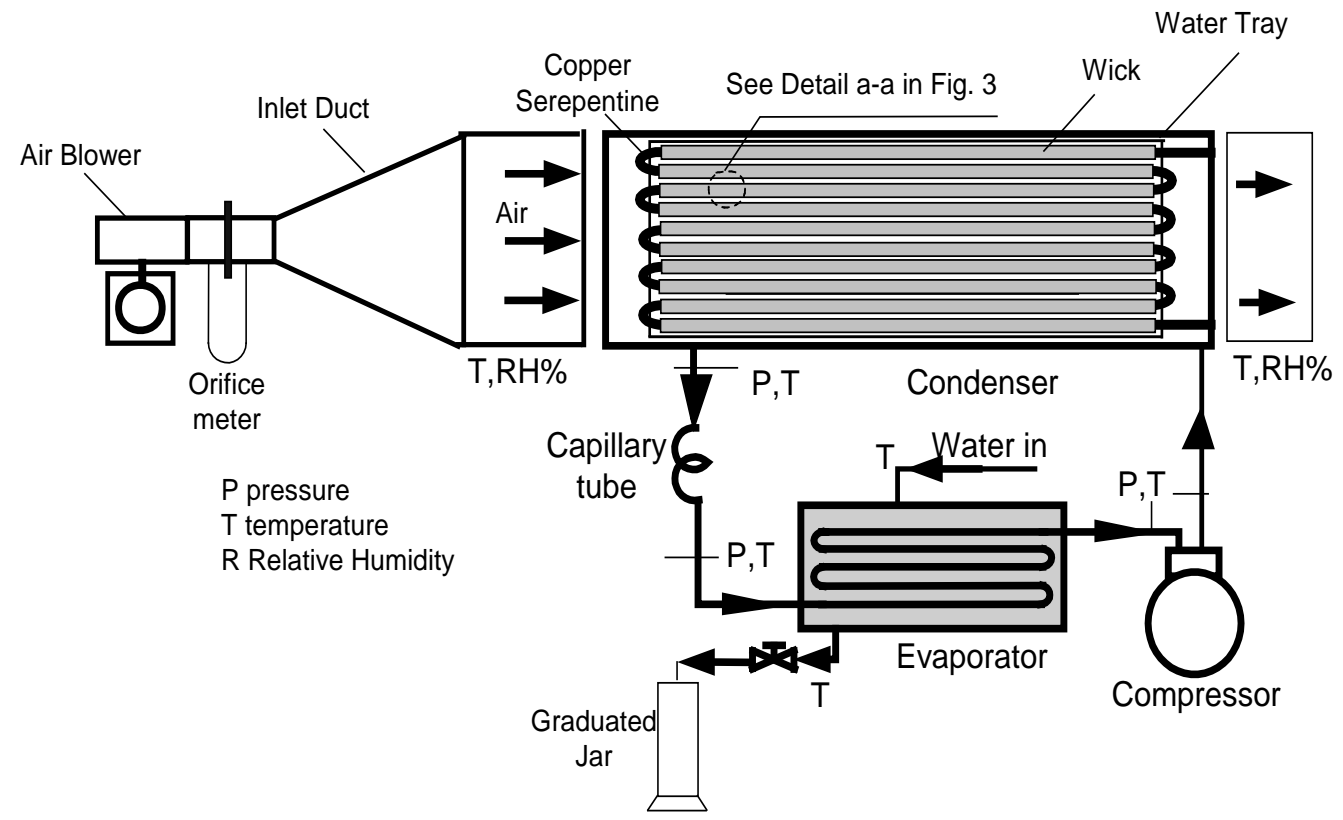

Fig. 1 Layout of the experimental apparatus

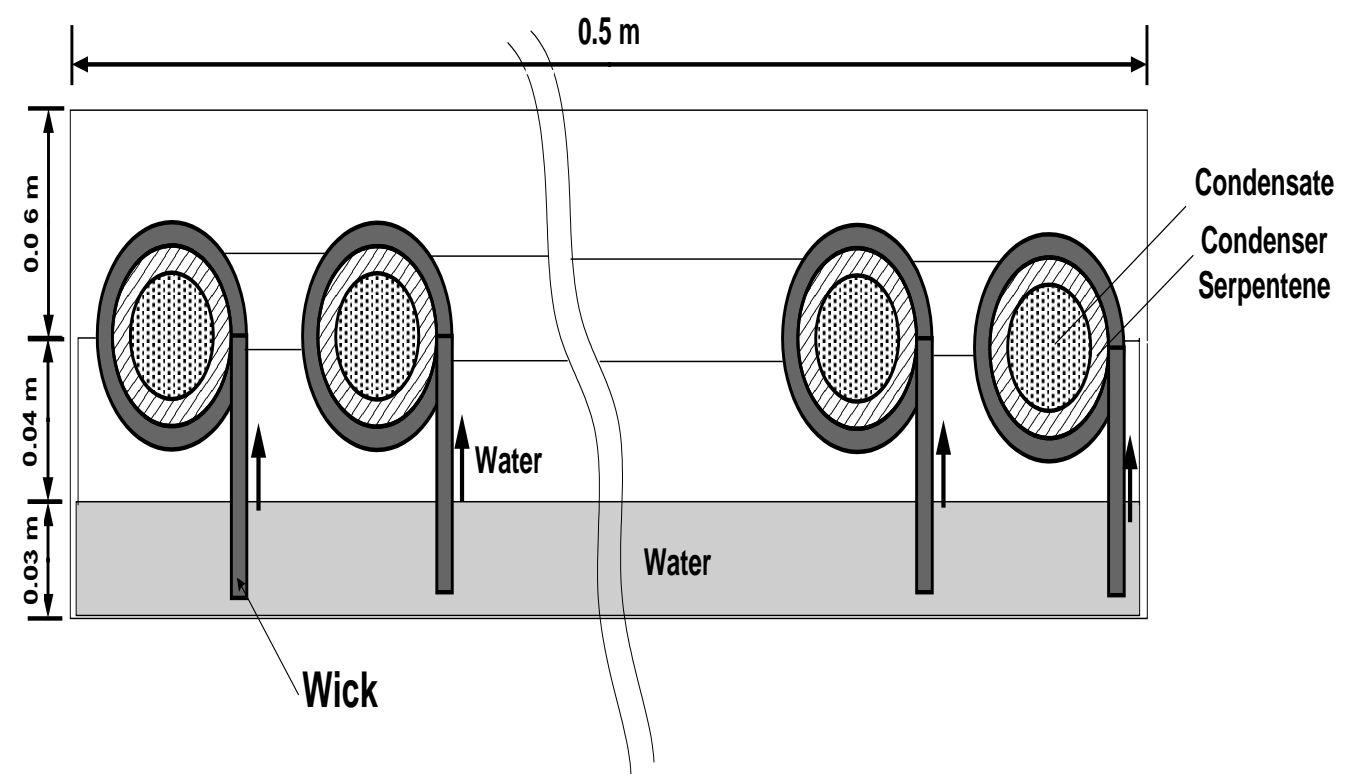

Fig. 2 Evaporative Condenser 
Table 1 Experimented Condenser Parameters

\begin{tabular}{lc}
\hline Rectangular Duct Width [m] & 0.5 \\
Rectangular Duct Height [m & 0.13 \\
Test Section Rectangular Duct Length [m] & 0.9 \\
Water Height in Tray [m] & 0.03 \\
Fibrous Sheet Height above water Surface [m] & 0.04 \\
Condenser Serpentine Specifications: & \\
Material & copper \\
Number of Tubes & 10 \\
Pitch between tubes & 0.05 \\
Tube Inner Diameter & 0.008 \\
Length of Serpentine & 0.9 \\
Outer Heat Transfer Area Of Serpentine [m $\left.{ }^{2}\right]$ & 0.283 \\
Outer Heat Transfer Area Of Serpentine per unit Volume $\left[\mathrm{m}^{2} / \mathrm{m}^{3}\right]$ & 5.3 \\
\hline
\end{tabular}

Temperatures of refrigerant, air, and water at different points of the cycle were recorded with T-Type thermocouples. The accuracy of thermocouples, as calibrated, is $\pm 0.2{ }^{\circ} \mathrm{C}$. The error in pressure measurement is For refrigerant temperature measurement, the surface of tubes was cleaned and then the thermocouple probes were soldered on the surface. An insulating tape was wrapped around the tube to prevent any convection effect of ambient air on the temperature readings. The pressure at the different locations of the cycle was measured by dial type pressure gauges suitable for the refrigeration system. The error in pressure measurement is $\pm \underline{0.5 \% \text { of the full }}$ scale. The relative humidity at inlet and outlet of the condenser test section were measured by digital hygrometer. The air flow rate was controlled by gate at the suction side of the blower. It was measured by orifice plate connected with U-tube manometer. The water flow rate through the evaporator was measured by graduated jar and stop watch.

\section{3- EVAPORATIVE CONDENSER THEORETICAL MODEL}

An elemental volume in the evaporative condenser along air flow is shown in Fig. 3. 


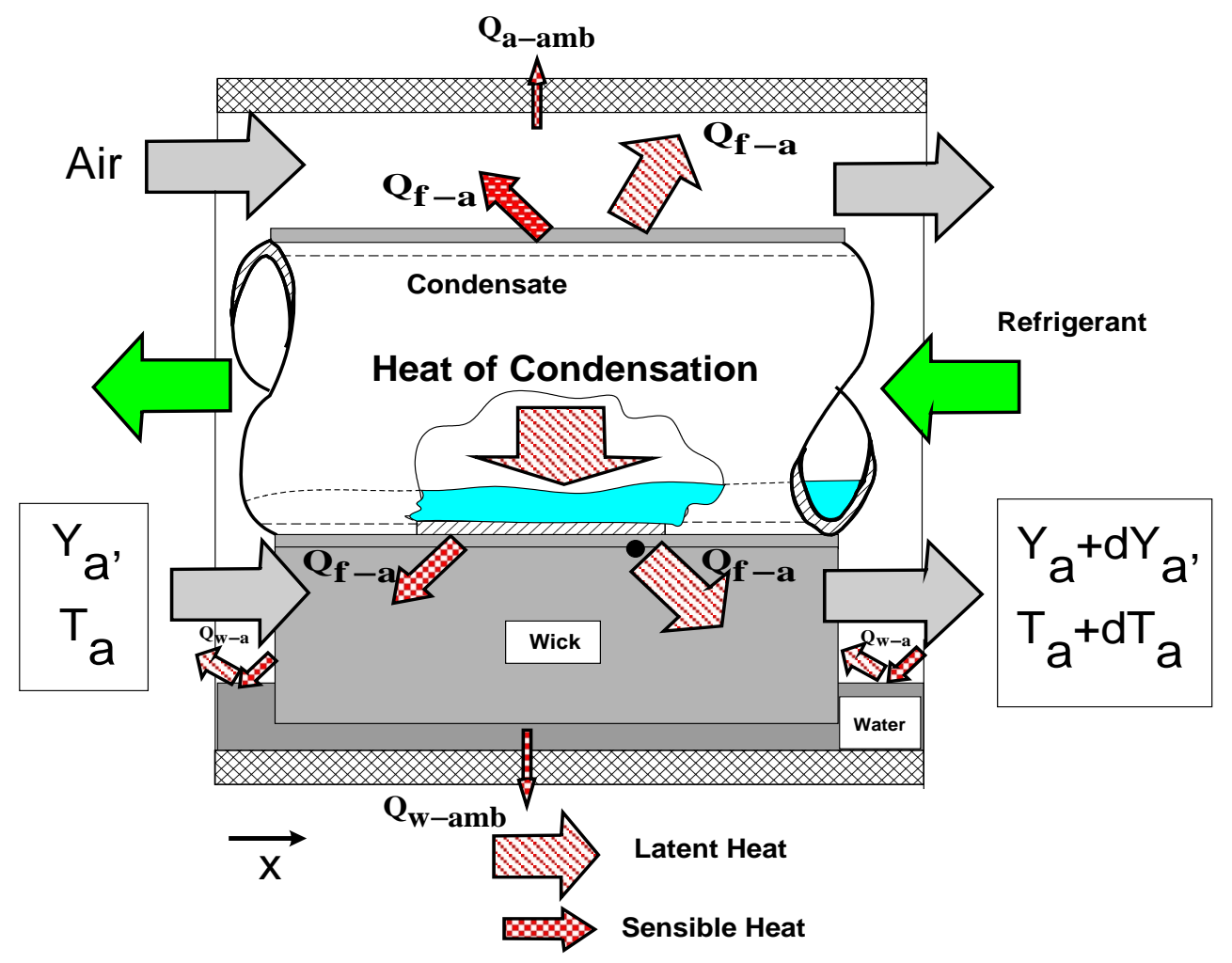

Fig. 3. An elemental volume of the evaporative condenser

Air enters the channel of the condenser and paths over the wetted serpentine, the cloth sheets, and the shallow layer of water in the basin. During its path, simultaneous heat and mass transfer between the air wetted surfaces, and water takes place. The driving force for mass transfer is the difference between the specific humidities at the wetted interfaces and the bulk air.

The following assumptions are considered:

1. Heat resistance through the water layer in the basin was neglected. Accordingly, temperature at interface was equal to the bulk water temperature.

2. Heat is transferred by conduction from the outer surface of serpentine to the outer surface of cloth sheet around it. The conduction in the axial direction was neglected.

3. Surface of the cloth sheets around the tubes of the serpentine was completely wetted.

4. The temperature of the vertical layers of sheet strips, which compensate water for the serpentine, was assumed to be equal to the temperature of water in the basin.

5. The inlet sensible heat of the compensated water to the serpentine was neglected as compared with the latent heat due to evaporation from it.

Taking an elemental volume of length $\Delta \mathrm{x}$ in the direction of air flow, the governing equations of heat and mass transfer, which takes place inside the evaporative 
condenser solely by considering the mass flow rate of refrigerant as a parameter, were given as

An energy balance of the air:

$$
\begin{aligned}
& Q_{s, f \rightarrow a}=h_{f \rightarrow a}\left(2 \pi r_{f o} \times n_{t}\right) \Delta x\left(T_{f o}-T_{a}\right) \\
& Q_{s, a \rightarrow w}=h_{a \rightarrow w}\left(W_{b}+2 n_{t} H_{f}\right) \Delta x\left(T_{a}-T_{w}\right) \\
& Q_{s, a \rightarrow a m b}{ }_{a \rightarrow a m b}\left[2\left(H_{d}-H_{l b}\right)+W_{b}\right] \Delta x\left(T_{a}-T_{a m b}\right) \\
& d T_{a} \\
& \frac{Q_{s, f} a}{d x}=\frac{m_{a}\left(C p_{a}+Q_{a} C_{p v}\right) \Delta x}{A}-Q s, a \rightarrow a m b
\end{aligned}
$$

A mass balance of the air:

$$
\begin{aligned}
& \mathrm{m}_{\mathrm{v}, \mathrm{fo} \rightarrow \mathrm{a}}=\mathrm{k}_{\mathrm{m}, \mathrm{fo} \rightarrow \mathrm{a}}\left(2 \pi \mathrm{r}_{\mathrm{fo}} \times \mathrm{n}_{\mathrm{t}}\right) \Delta \mathrm{x}\left(\mathrm{Y}_{\mathrm{fo}}^{*}-\mathrm{Y}_{\mathrm{a}}\right) \\
& \mathrm{m}_{\mathrm{v}, \mathrm{w} \rightarrow \mathrm{a}}^{\cdot}=\mathrm{k}_{\mathrm{m}, \mathrm{w} \rightarrow \mathrm{a}}\left(\mathrm{W}_{\mathrm{b}}+2 \mathrm{n}_{\mathrm{t}} \mathrm{H}_{\mathrm{f}}\right) \Delta \mathrm{x}\left(\mathrm{Y}_{\mathrm{W}}^{*}-\mathrm{Y}_{\mathrm{a}}\right) \\
& \frac{\mathrm{dYa}}{\mathrm{dx}}=\frac{\mathrm{m}_{\mathrm{v}, \mathrm{fo} \rightarrow \mathrm{a}}^{\cdot}+\mathrm{m}_{\mathrm{v}, \mathrm{w} \rightarrow \mathrm{a}}}{\mathrm{m}_{\mathrm{a}} \Delta \mathrm{x}}
\end{aligned}
$$

The interfacial specific humidity at wetted surfaces interfaces was given from the data given in air property tables as:

$\mathrm{Y}_{\mathrm{fo}}^{*}=\mathrm{f}\left(\mathrm{T}_{\mathrm{fo}}\right), \mathrm{Y}_{\mathrm{W}}^{*}=\mathrm{f}\left(\mathrm{T}_{\mathrm{W}}\right)$

The boundary conditions of equations (4),and (7) are given as:

$\mathrm{T}_{\mathrm{a}}(\mathrm{x}=0)=\mathrm{T}_{\mathrm{amb}}$.

$\mathrm{Y}_{\mathrm{a}}(\mathrm{x}=0)=\mathrm{Y}_{\mathrm{amb}}$.

The outer wet fabric temperature is obtained by energy balance at fabric-air interface:

$$
\begin{aligned}
& \mathrm{U}_{\mathrm{C} \rightarrow \mathrm{fo}}\left(\mathrm{T}_{\mathrm{C}}-\mathrm{T}_{\mathrm{fo}}\right)=\mathrm{h}_{\mathrm{f} \rightarrow \mathrm{a}}\left(\mathrm{T}_{\mathrm{fo}}-\mathrm{T}_{\mathrm{a}}\right)+\mathrm{k}_{\mathrm{m}, \mathrm{fo}_{\rightarrow} \mathrm{a}}\left(\mathrm{Y}_{\mathrm{fo}}^{*}-\mathrm{Y}_{\mathrm{a}}\right) \mathrm{h}_{\mathrm{fg}, \mathrm{w}} \\
& \mathrm{Q}_{\mathrm{C}}=\mathrm{m}_{\mathrm{r}} \mathrm{h}_{\mathrm{fg}, \mathrm{r}}\left(\mathrm{T}_{\mathrm{C}}\right)
\end{aligned}
$$

Energy balance at basin water interface, with the consideration that the area of interface between the water and the air is the area of water surface plus the area of the vertical strips protruding from water basin to the tubes, was given as:

$$
\begin{aligned}
\mathrm{hw} \rightarrow \mathrm{a}\left(\mathrm{T}_{\mathrm{a}}-\mathrm{T}_{\mathrm{W}}\right)=\mathrm{U}_{\mathrm{w} \rightarrow \mathrm{amb}} \cdot \frac{\mathrm{W}_{\mathrm{b}}}{\left(\mathrm{W}_{\mathrm{b}}+2 \mathrm{n}_{\mathrm{t}} \mathrm{H}_{\mathrm{f}}\right)}\left(\mathrm{T}_{\mathrm{w}}-\mathrm{T}_{\mathrm{amb}}\right) & \\
& +\mathrm{k}_{\mathrm{m}, \mathrm{w} \rightarrow \mathrm{a}}\left(\mathrm{Y}_{\mathrm{w}}^{*}-\mathrm{Y}_{\mathrm{a}}\right) \mathrm{h}_{\mathrm{fg}, \mathrm{w}}
\end{aligned}
$$

The heat transfer coefficients between the air and wetted surfaces $\mathrm{h}_{\mathrm{fo} \rightarrow \mathrm{a}}, \mathrm{h}_{\mathrm{W} \rightarrow \mathrm{a}}$ were given as follows [6] : 
For turbulent flow

$\mathrm{Nu}=0.023 \mathrm{Re}^{0.8} \operatorname{Pr}^{\mathrm{n}}$

where

$$
\begin{aligned}
& n=0.4 \text { for heating } \\
& n=0.3 \text { for cooling }
\end{aligned}
$$

and for laminar flow is :

$$
\frac{\mathrm{h}_{0} \mathrm{D}_{\mathrm{eq}}}{\lambda_{\mathrm{a}}}=3.66+\frac{0.0668\left(\frac{2 \mathrm{r}_{\mathrm{f}_{0}}}{\mathrm{~L}_{\mathrm{c}}}\right) \mathrm{Re}_{\mathrm{a}} \mathrm{Pr}_{\mathrm{a}}}{0.04\left[\left(\left(\frac{2 \mathrm{r}_{\mathrm{fo}}}{\mathrm{L}_{\mathrm{c}}}\right) \operatorname{Re}_{\mathrm{a}} \mathrm{Pr}_{\mathrm{a}}\right)^{0.67}\right]+1}
$$

Where,

$$
\begin{aligned}
& \operatorname{Re}_{\mathrm{a}}=\frac{\rho_{\mathrm{a}} \mathrm{V}_{\mathrm{a}} \mathrm{D}_{\mathrm{O}}}{\mu_{\mathrm{a}}}, \quad \operatorname{Pr}_{\mathrm{a}}=\frac{\mu_{\mathrm{a}} \mathrm{Cp} \mathrm{a}}{\lambda_{\mathrm{a}}} \\
& \mathrm{D}_{\mathrm{eq}}=\frac{4 \times \text { cross sectional area }}{\text { wetted priemeter }} \\
& \mathrm{h}=\frac{\mathrm{Nu} \times \lambda_{\mathrm{a}}}{\mathrm{D}_{\text {eq }}}
\end{aligned}
$$

When $\mathrm{Le}=1.0$, then:

$$
\mathrm{k}_{\mathrm{m}}=\frac{\mathrm{h}}{\mathrm{C}_{\mathrm{pa}}}
$$

The overall heat transfer coefficient between refrigerant in condenser and outer surface of condenser

$$
\mathrm{U}_{\mathrm{C} \rightarrow \mathrm{fo}}=\frac{1}{\frac{1}{\mathrm{~h}_{\mathrm{i}}} \frac{\mathrm{r}_{\mathrm{fo}}}{\mathrm{r}_{\mathrm{i}}}+\frac{\mathrm{r}_{\mathrm{fo}}}{\lambda_{\mathrm{t}}} \ln \frac{\mathrm{r}_{0}}{\mathrm{r}_{\mathrm{i}}}+\frac{\mathrm{r}_{\mathrm{fo}}}{\lambda_{\mathrm{f}}} \ln \frac{\mathrm{r}_{\mathrm{fo}_{0}}}{\mathrm{r}_{\mathrm{o}}}}
$$

The connective heat transfer, $h_{i}$, between the refrigerant and inner tube condenser, $h_{I}$, was given as [7]:

$$
\frac{\mathrm{h}_{\mathrm{i}} \mathrm{D}_{\mathrm{i}}}{\lambda_{\mathrm{lr}}}=0.026\left(\frac{\mathrm{C}_{\mathrm{p}} \mu}{\lambda_{\mathrm{l}}}\right)^{1 / 3}\left(\frac{\mathrm{DG}_{\mathrm{e}}}{\mu_{\mathrm{lr}}}\right)^{0.8}
$$

where

$$
G_{e}=G_{V r}\left(\frac{\rho_{l r}}{\rho_{\mathrm{Vr}}}\right)^{0.5}+G_{l r}
$$

The overall heat transfer coefficient between the air inside the duct and the ambient air outside it, $\mathrm{U}_{\mathrm{a} \rightarrow \mathrm{amb}}$, $\mathrm{s}$ given as : 


$$
\mathrm{U}_{\mathrm{a} \rightarrow \mathrm{amb} .}=\frac{1}{\frac{1}{\mathrm{~h}_{\mathrm{dwo}}}+\frac{\delta_{\text {in }}}{\lambda_{\text {in }}}+\frac{1}{\mathrm{~h}_{\mathrm{dwi}}}}
$$

The approximate overall heat transfer coefficient between the shallow layer of water in basin and outside ambient air , $\mathrm{U}_{\mathrm{W} \rightarrow \mathrm{amb}}$, is given as :

$$
\mathrm{U}_{\mathrm{W} \rightarrow \mathrm{amb} .}=\frac{1}{\frac{\mathrm{H}_{\mathrm{lb}}}{2 \lambda_{\mathrm{w}}}+\frac{\delta \text { in }}{\lambda \text { in }}+\frac{1}{\mathrm{~h}_{\mathrm{dwo}}}}
$$

Equations (1)-(19) were solved numerically to study the thermal performance of the evaporative condenser separate from the cycle by taking the mass flow of refrigerant as a parameter in this study.

The input data to the program are:

1. The evaporator condenser design parameters.

2. Inlet air temperature and humidity.

3. The physical properties of the air.

4. The physical properties of R12.

5. The data of air specific humidity $\mathrm{Y}^{*}$ as a function of $\mathrm{T}_{\mathrm{W}}$

The differential equations were numerically solved with fourth order Runge Kutta method simultaneously with the other algebraic starting from the air inlet side of condenser.

\section{4- EXPERIMENTAL RESULTS AND MODEL VALIDATION}

\subsection{Experimental Results}

Due to the difficulties in controlling the air inlet condition to the condenser, the experimental results were only employed to ascertain the validity of model, and to quantify the performance of residential refrigerator when equipped with the evaporative condenser at its normal operation.

For each experimental condition, measurements of all the variables were taken after the establishment steady state conditions.

The evaporator capacity was calculated from the measured values of inlet and outlet temperatures of water flowing through the evaporator:

$\mathrm{Q}_{\mathrm{e}}=\mathrm{m}_{\mathrm{W}} \mathrm{C}_{\mathrm{W}}\left(\mathrm{T}_{\mathrm{wi}}-\mathrm{T}_{\mathrm{WO}}\right)$

The refrigerant mass flow rate was calculated by dividing $\mathbf{Q}_{\mathbf{e}}$ by the actual refrigerant enthalpy difference through the evaporator

$$
\dot{m_{r}}=\frac{Q_{e}}{i_{e, 0}-i_{e, i}}
$$

The condenser heat capacity was calculated as 
$\mathrm{QC}_{\mathrm{C}}=\mathrm{m}_{\mathrm{r}}\left(\mathrm{i}_{\mathrm{C}, \mathrm{i}}-\mathrm{i}_{\mathrm{C}, 0}\right)$

This value of $\mathbf{Q}_{\mathbf{c}}$ was confirmed by making condenser air side energy balance as:

$\mathrm{Qc}=\rho_{\mathrm{a}} \mathrm{V}_{\mathrm{a}}\left(\mathrm{i}_{\mathrm{a}, 0}-\mathrm{i}_{\mathrm{a}, \mathrm{i}}\right)$

Where, $\mathbf{V}_{\mathbf{a}}$ is the air volume flow rate, and was measured using the standard orifice meter. The following equation was used [8]

$V_{a}=K A_{o} \sqrt{\frac{2 \Delta p}{\rho_{a}}}$

The specific work of the compressor was calculated:

$\mathrm{w}_{\mathrm{C}}=\left(\mathrm{i}_{\text {Com, } \mathrm{o}}-\mathrm{i}_{\text {Com, } \mathrm{i}}\right)$

The coefficient of performance of the refrigerating cycle was given as

$\mathrm{COP}=\frac{\left(\mathrm{i}_{\mathrm{e}, 0}-\mathrm{i}_{\mathrm{e}, \mathrm{i}}\right)}{\left(\mathrm{i}_{\mathrm{com}, 0}-\mathrm{i}_{\mathrm{com}, \mathrm{i}}\right)}$

The condenser heat capacity was calculated by Eq. 22 by making an energy balance for the air side. Many tests were performed to determine the effect of the evaporative condenser on the performance of the refrigerating cycle.

Table 2. Experimental results for six selective test runs

(a)

\begin{tabular}{|l|l|c|c|c|}
\hline parameter & \multicolumn{1}{|c|}{ unit } & test run1 & test run 2 & test run 3 \\
\hline $\mathrm{T}_{\mathrm{db}, \text { in }}$ & ${ }^{\circ} \mathrm{C}$ & 31 & 31 & 31 \\
$\mathrm{~V}$ & $\mathrm{~m} / \mathrm{s}$ & 1.1 & 1.1 & 1.1 \\
$\mathrm{~T}_{\mathrm{db}, \text { out }}$ & ${ }^{\circ} \mathrm{C}$ & 31 & 32 & 31.5 \\
$\mathrm{y}_{\mathrm{ai}}$ & $\mathrm{kgv} / \mathrm{kg}_{\mathrm{a}}$ & 0.0133 & 0.0133 & 0.0133 \\
$\mathrm{y}_{\mathrm{o}}$ & $\mathrm{kgv} / \mathrm{kg}_{\mathrm{a}}$ & 0.0157 & 0.0156 & 0.01613 \\
$\mathrm{t}_{\mathrm{c}}$ & ${ }^{\circ} \mathrm{C}$ & 51 & 53.4 & 55 \\
$\mathrm{t}_{\mathrm{e}}$ & ${ }^{\circ} \mathrm{C}$ & -7 & -4.5 & -2.5 \\
$\mathrm{~m}_{\mathrm{r}}$ & $\mathrm{kg} / \mathrm{s}$ & 0.002782 & 0.003223 & 0.0036 \\
$\mathrm{Q}_{\mathrm{c}}$ & $\mathrm{W}$ & 382.00 & 436 & 482 \\
$\mathrm{qe}$ & $\mathrm{kJ} / \mathrm{kg}$ & 98.51 & 97.22 & 96.2 \\
$\mathrm{w}_{\mathrm{c}}$ & $\mathrm{kJ} / \mathrm{kg}$ & 38.33 & 36.55 & 35.63 \\
$\mathrm{cop}$ & & 2.57 & 2.66 & 2.7 \\
\hline
\end{tabular}

\begin{tabular}{|l|l|c|c|c|}
\hline parameter & unit & test run 4 & test run 5 & test run 6 \\
\hline $\mathrm{T}_{\mathrm{db}, \text { in }}$ & ${ }^{\circ} \mathrm{C}$ & 29 & 29 & 29 \\
$\mathrm{~V}$ & $\mathrm{~m} / \mathrm{s}$ & 2.5 & 2.5 & 2.5 \\
$\mathrm{~T}_{\mathrm{db}, \text { out }}$ & ${ }^{\circ} \mathrm{C}$ & 29.7 & 28.2 & 27.6 \\
$\mathrm{y}_{\mathrm{ai}}$ & $\mathrm{kgv} / \mathrm{kg}_{\mathrm{a}}$ & 0.00936 & 0.00936 & 0.00936 \\
$\mathrm{y}_{0}$ & $\mathrm{kgv} / \mathrm{kg}_{\mathrm{a}}$ & 0.01035 & 0.0111 & 0.0113 \\
$\mathrm{t}_{\mathrm{c}}$ & ${ }^{\circ} \mathrm{C}$ & 42.25 & 44.5 & 45 \\
$\mathrm{t}_{\mathrm{e}}$ & ${ }^{\circ} \mathrm{C}$ & $\mathbf{- 8}$ & -4 & -2 \\
$\mathrm{~m}_{\mathrm{r}}$ & $\mathrm{kg} / \mathrm{s}$ & 0.003292 & 0.003551 & 0.00372 \\
$\mathrm{Q}_{\mathrm{c}}$ & $\mathrm{W}$ & 467.00 & 495 & 515.00 \\
$\mathrm{qe}$ & $\mathrm{kJ} / \mathrm{kg}$ & 107.21 & 119.40 & 107 \\
$\mathrm{w}_{\mathrm{c}}$ & $\mathrm{kJ} / \mathrm{kg}$ & 34.63 & 37.45 & 30.14 \\
$\mathrm{cop}$ & & 3.096 & 3.19 & 3.55 \\
\hline
\end{tabular}

Six sample test runs were selected and their results are shown in table 2(a,b).. In table 2a, the inlet parameters are kept constant at: $31{ }^{\circ} \mathrm{C}, 47.1 \%$, and $1.1 \mathrm{~m} / \mathrm{s}$ for dry bulb temperature, relative humidity and air velocity respectively. While these parameters are $29^{\circ} \mathrm{C}, 37.5 \%$, and $2.5 \mathrm{~m} / \mathrm{s}$ for the experiments listed at table $3 \mathrm{~b}$.

Table 2a shows that when the evaporator temperature increases from $-7^{\circ} \mathrm{C}$ to $-2,5^{\circ} \mathrm{C}$, the percentage increase in COP is $5 \%$. While, in Table $2 \mathrm{~b}$, it is $15 \%$ when increasing the evaporator temperature from $-8{ }^{\circ} \mathrm{C}$ to $-2{ }^{\circ} \mathrm{C}$. That is due to that the 
condenser temperature is not sensitive to the variation in evaporator temperatures in cases (b) as compared with the cases in (a). Table 2a shows that the condenser temperature increase $0.88{ }^{\circ} \mathrm{C}$ for each $1^{\circ} \mathrm{C}$ increase in evaporator temperature, while it increases $0.45^{\circ} \mathrm{C}$ for the experiments in table $2 \mathrm{~b}$.

\subsection{Model Validation}

A set of six experimental data points were used to compare with the data produced from the theoretical results. Table 3 shows these comparison for the same design and inlet parameters,. The compared data were the outlet air temperature, outlet air specific humidity, condenser average heat flux, and condenser temperature respectively. The columns titled with variation shows the percent variation between the experimental and theoretical values. The general trends in Table 3 shows that the theoretical results agreed reasonably with the experimental results. Therefore this model can be used to predict the effect of the different parameters on the performance of the suggested condenser

- Table 3 Comparison of the theoretical model with the experimental data

\begin{tabular}{|c|c|c|c|c|c|c|c|c|c|c|c|}
\hline \multirow[t]{3}{*}{ Test run } & \multirow{3}{*}{$\begin{array}{c}\text { Ref. Mass } \\
\text { flow rate } \\
{[\mathrm{kg} / \mathrm{s}]}\end{array}$} & \multicolumn{3}{|c|}{$\begin{array}{c}\text { Air Temperature } \\
{[\text { deg C] }}\end{array}$} & \multicolumn{3}{|c|}{$\begin{array}{c}\text { Air Specific Humidity } \\
\mathrm{kgv} / \mathrm{kga}\end{array}$} & \multicolumn{2}{|c|}{$\begin{array}{c}\text { Condenser heat flux } \\
\text { [W/m2] }\end{array}$} & \multicolumn{2}{|c|}{$\begin{array}{c}\text { Condenser Temperature } \\
{[\text { deg C] }}\end{array}$} \\
\hline & & & outlet & outlet & & outlet & outlet & & & & \\
\hline & & inlet & Exp. & model & inlet & Exp. & model & Exp & model & Exp & model \\
\hline & \multicolumn{11}{|c|}{ Air Velocity $1.1 \mathrm{~m} / \mathrm{s}$} \\
\hline 1 & 0.00278 & 31 & 31 & 30.55 & 0.0133 & 0.0157 & 0.0164 & 1286 & 1265 & 51 & 50.75 \\
\hline 2 & 0.00322 & 31 & 32 & 30.65 & 0.0133 & 0.0156 & 0.0168 & 1468 & 1465 & 53.4 & 53.5 \\
\hline \multirow[t]{2}{*}{3} & 0.0036 & 31 & 31.5 & 30.7 & 0.0133 & 0.016 & 0.017 & 1623 & 1585 & 55 & 55 \\
\hline & \multicolumn{11}{|c|}{ Air Velocity $2.5 \mathrm{~m} / \mathrm{s}$} \\
\hline 4 & 0.00329 & 29 & 29.7 & 28.2 & 0.00936 & 0.01035 & 0.0112 & 1572 & 1566 & 42.25 & 43.5 \\
\hline 5 & 0.00355 & 29 & 28.2 & 28.2 & 0.00936 & 0.0111 & 0.0113 & 1666 & 1676 & 44.5 & 44.75 \\
\hline 6 & 0.00372 & 29 & 27.6 & 28.3 & 0.00936 & 0.0113 & 0.0113 & 1734 & 1707 & 45 & 45 \\
\hline
\end{tabular}

\section{THEORETICAL RESULTS AND DISCUSSION}

Considering the refrigerant mass flow rate as an input parameter, the model was used to predict the temperatures, and the specific humidifies of air along the condenser. These are important properties for the enhancement of the condenser cooling process. The design parameters that have been kept constant are listed in table 4 .

The temperature and specific humidity distributions along the length of condenser are shown in Fig. 4. Figure 4 shows that the air temperature decreases with increasing the length of condenser. This is due to the evaporative cooling of air by the water in the basin, and the vertical sheets of cloth. The decreasing trend is higher at low inlet relative humidity (Fig. 4e), because of the better evaporative cooling at drier weather conditions and this is confirmed by the driving force for mass transfer , $\Delta \mathrm{Y}$ (Fig. 4f). 
Table 4 Condenser design parameters input to the theoretical

Rectangular Duct Width [m]

1

Rectangular Duct Height [m]

0.08

Test Section Rectangular Duct Length [m]

1

Water Height in Tray [m]

0.03

Fibrous Sheet Height above water Surface [m]

0.01

Condenser Serpentine Specifications:

Material

Copper

Number of Tubes [-]

Pitch between tubes [m]

0.02

Tube Inner Diameter [m]

0.008

Length of Serpentine [m]

Outer Heat Transfer Area Of Serpentine $\left[\mathrm{m}^{2}\right]$

Outer Heat Transfer Area Of Serpentine per unit Volume $\left[\mathrm{m}^{2} / \mathrm{m}^{3}\right]$

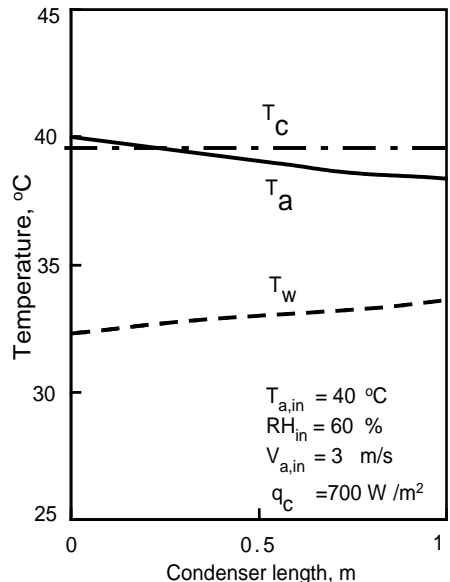

(a)

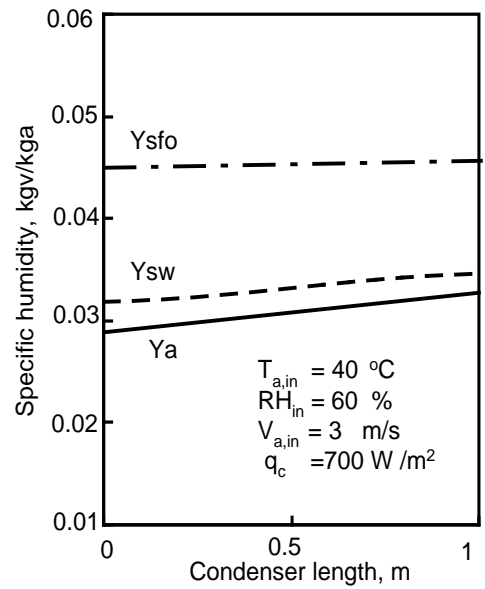

(b)

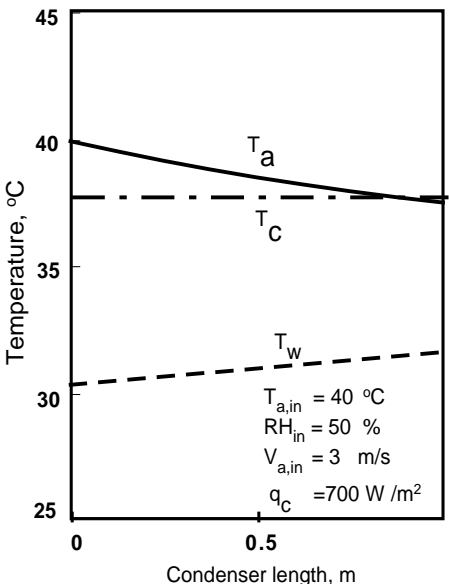

(c)

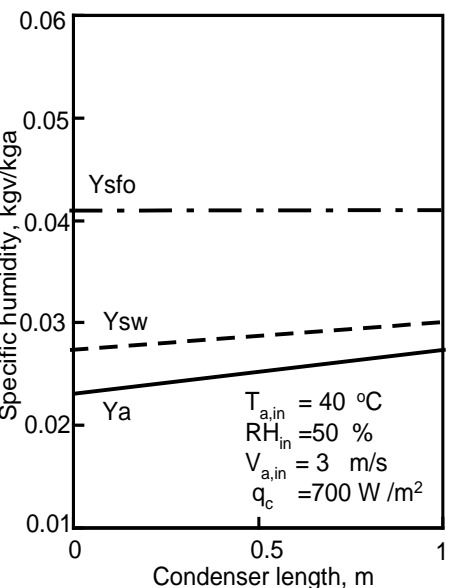

(d)

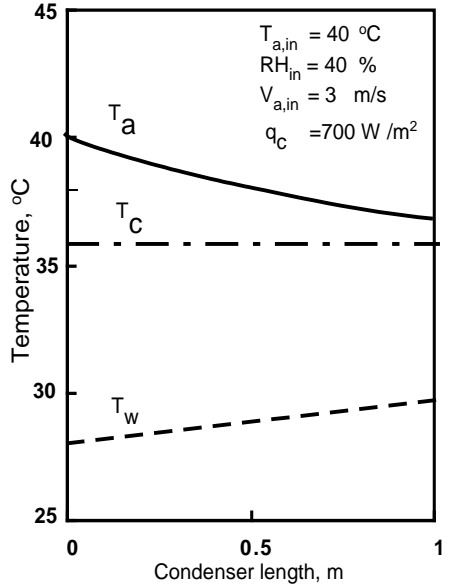

(e)

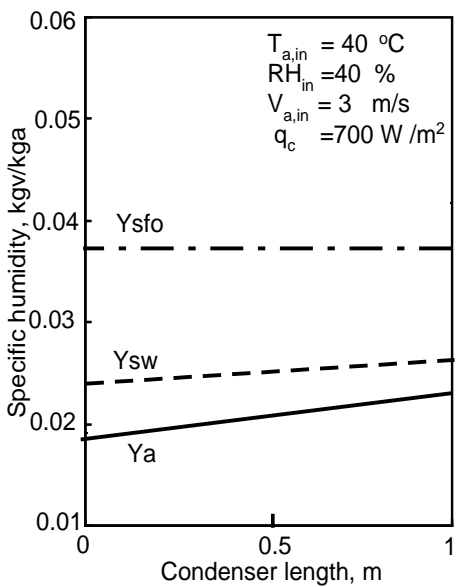

(f)

Fig. 4 Temperature and specific humidity profiles for different air inlet relative humilities 
Since the COP is strong function of the condensing temperature, $T_{c}$, the effect of the different parameters on this temperature are considered. Figure 5 shows the effect of relative humidity on the condensing temperature at various air velocities. The condensing temperature decreases exponentially with increasing the air velocity from 0.5 to $5 \mathrm{~m} / \mathrm{s}$. The dashed line represents the air inlet temperature. For the average heat flux of $700 \mathrm{~W} / \mathrm{m}^{2}$ and air velocity lower than $1.75 \mathrm{~m} / \mathrm{s}$, the condensing temperature is higher than the air inlet temperature within the relative humidity range from 20 to $80 \%$, while at velocity higher than $3 \mathrm{~m} / \mathrm{s}$, the condenser temperature is lower than the air inlet temperature within a relative humidity range from 20 to $60 \%$. At air inlet relative humidity of $80 \%$, the condensing temperature always is higher than the air inlet temperature.

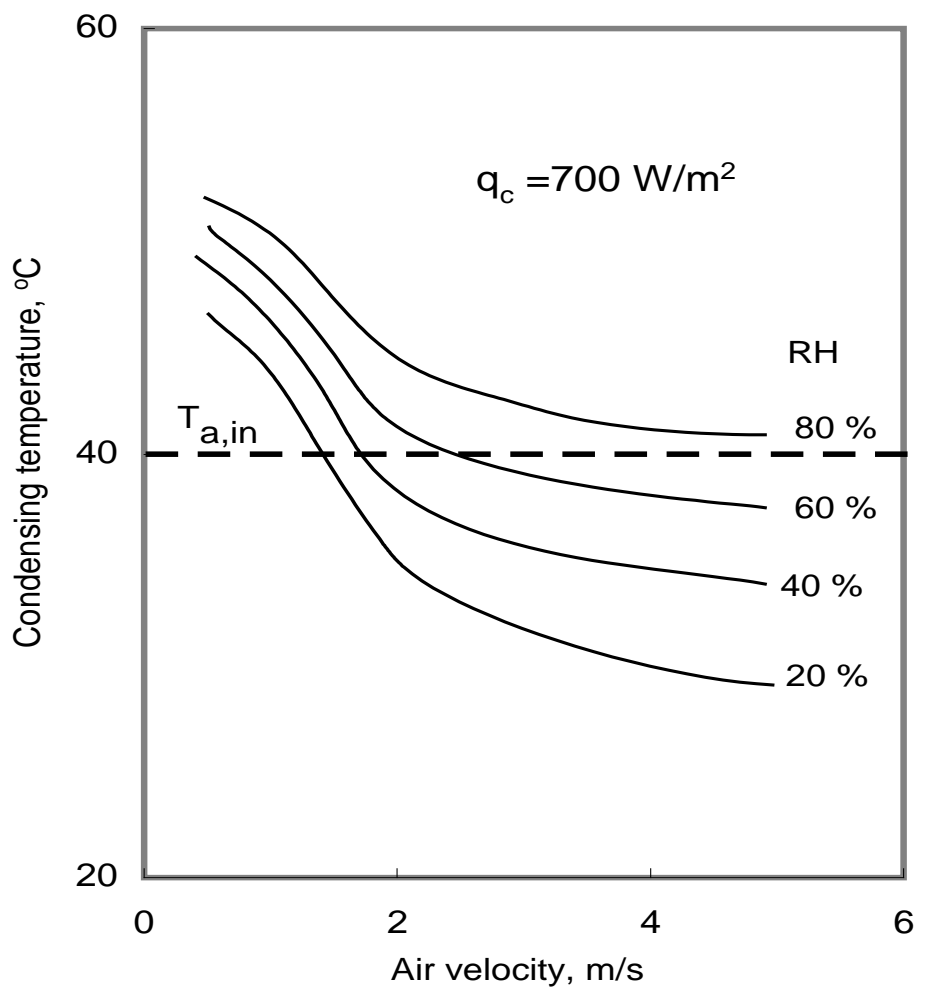

Fig. 5. Effect of the relative humidity on the condensing temperature at various air velocities

Figure 6 shows the effect of air velocity on condensing temperature of air cooled and evaporative condensers at various condenser average heat fluxes. For air inlet velocity of $3 \mathrm{~m} / \mathrm{s}$, and condensing temperature of $47{ }^{\circ} \mathrm{C}$, the air cooled condenser rejects an average heat flux of $150 \mathrm{~W} / \mathrm{m}^{2}$ while it becomes $2000 \mathrm{~W} / \mathrm{m}^{2}$ for the evaporative condenser. This means that the evaporative condenser has the ability to reject heat 13 times higher than the air cooled condenser. For the average heat flux 
lower than $1000 \mathrm{~W} / \mathrm{m}^{2}$, the evaporative condenser temperature is lowered than the inlet temperature if the air velocity is higher than $2.75 \mathrm{~m} / \mathrm{s}$.

Figure 7 shows a comparison between condensing temperature of the air cooled and evaporative condensers for an average heat flux of $150 \mathrm{~W} / \mathrm{m}^{2}$. The results showed that the effect of air velocity on the condensing temperature of the evaporative condenser is negligibe at velocity higher than $3 \mathrm{~m} / \mathrm{s}$. Also the temperature of evaporative condenser can be decreased $20 \mathrm{oC}$ lower than that of the air cooled at 3 $\mathrm{m} / \mathrm{s}$ velocity

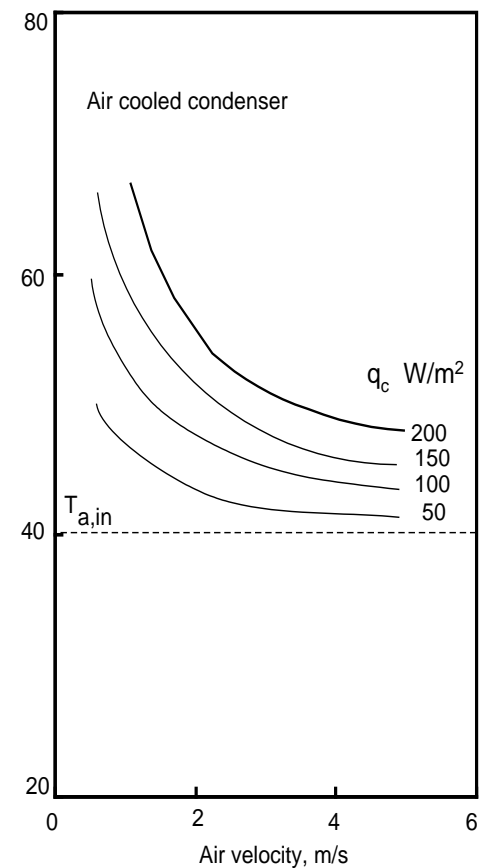

(a)

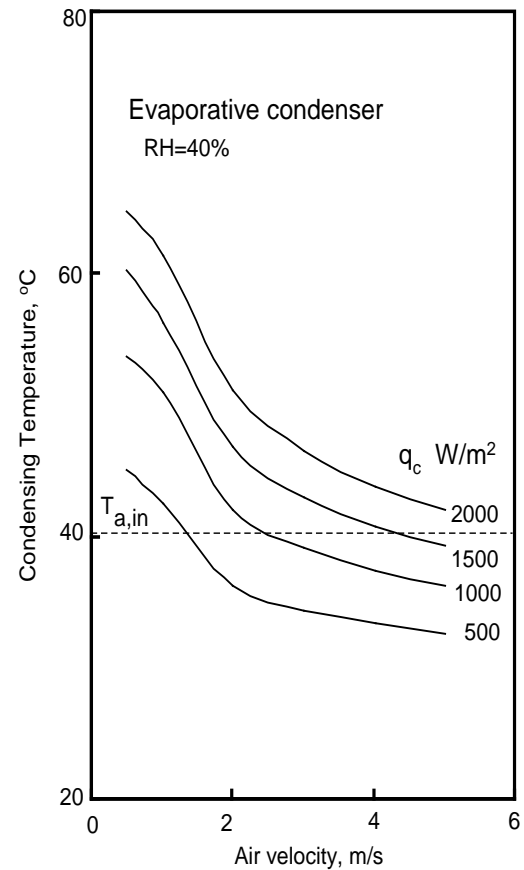

(b)

Fig. 6. Effect of air velocity on condensing temperature for various condenser average heat fluxes

\section{6- CONCLUSION}

An innovative evaporative cooled condenser for the use in small size refrigeration system was suggested and evaluated experimentally. The experimental results showed that the condenser temperature increases $0.45^{\circ} \mathrm{C}$ for each degree increase in evaporator temperature when the air velocity $2.5 \mathrm{~m} / \mathrm{s}$, and the ambient conditions is $29^{\circ} \mathrm{C}$ and the relative humidity is $37.5 \%$, Meanwhile, the condenser temperature increase is $0.88{ }^{\circ} \mathrm{C}$ in the case of air velocity $1.1 \mathrm{~m} / \mathrm{s}$ and ambient conditions of $31{ }^{\circ} \mathrm{C}$ and relative humidity of $47.1 \%$. A simple theoretical model for the heat and mass transfer processes inside the condenser have been developed and validated experimentally. The model was used to study the effect of the different parameters on the condensing 
temperature. Depending on the inlet relative humidity and air inlet velocity the condenser temperature decreases to a value lower than the inlet air temperature. The condenser temperature of evaporative condenser can be decreased $20{ }^{\circ} \mathrm{C}$ lower than the air cooled at velocity $3 \mathrm{~m} / \mathrm{s}$, condenser an average heat flux of $150 \mathrm{~W} / \mathrm{m}^{2}$, and the same inlet air condition.

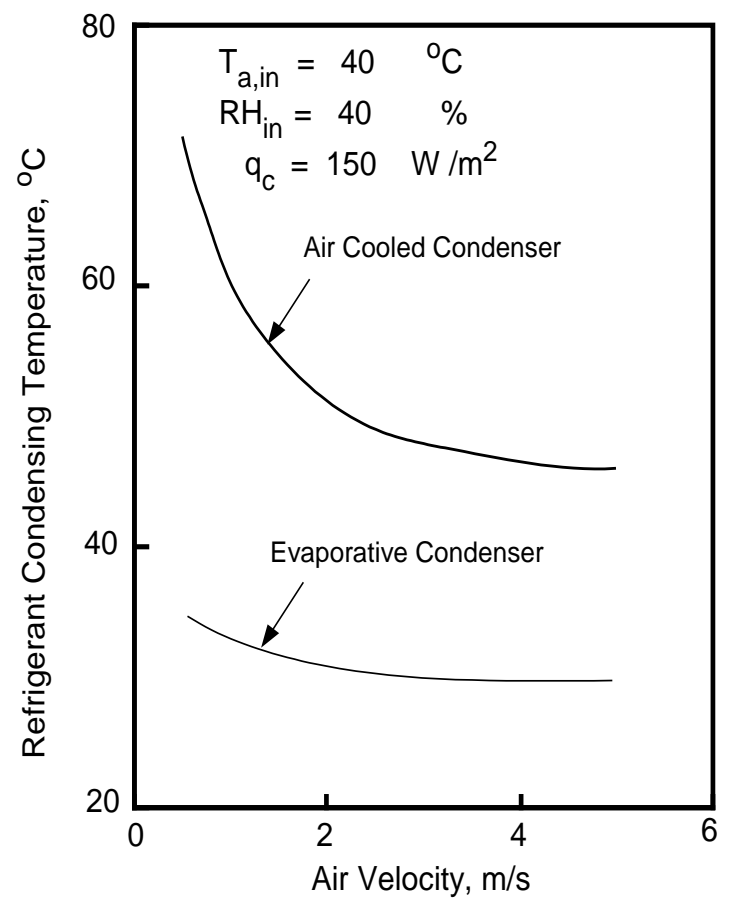

Fig. 7. Variations of refrigerant condensing temperature with air velocity for air cooled and evaporative condensers

For air inlet velocity of $3 \mathrm{~m} / \mathrm{s}$, and condensing temperature of $47{ }^{\circ} \mathrm{C}$, the air cooled condenser rejects an average heat flux of $150 \mathrm{~W} / \mathrm{m}^{2}$ while it becomes 2000 $\mathrm{W} / \mathrm{m}^{2}$ for the evaporative condenser. This means that the evaporative condenser has the ability to reject heat 13 times higher than the air cooled condenser.

Depending on the condenser heat capacity and air inlet conditions, the condenser can operate at a condensing temperature lower than the air inlet temperature

\section{7- REFEENCES}

[1] Dossat, R.J., Principal of Refrigeration, Prentice Hall, New Jersey, 1991.

[2] Brown W.K., Fundamental concepts integrating evaporative techniques in HVAC systems, ASHRAE Transactions 1990; 96 (Part1) :1227-35.

[3] Goswami Y., Mathur G.D, Kulkarni S.M., Experimental investigation of performance of a residential air conditioning system with an evaporatively cooled condenser, Journal of Solar Energy Engineering 1993;115:206-11. 
[4] Hajidavalloo E. Application of evaporative cooling on the condenser of windowair-conditioner J Applied Thermal Engineering 2007; 27:1937-43.

[5] Hwang Y, Radermacher R, Kopko W. An experimental evaluation of a residential-sized evaporatively cooled condenser. Int J Refrig 2001; 24:238-49.

[6] Holman J.P. Heat Transfer, Fifth ed., McGraw-Hill, 1981

[7] Arora CP, Refrigeration and air conditioning, $2^{\text {nd }}$ ed. . McGraw-Hill, New Delhi, 2000..

[8] Vennard J. K., Robert L. S., Elementary Fluid Mechanics, John Wiley\&Sons inc., 1976.

\section{دراسة تجريبية ونظريه علي مكثف ثلاجة منزليه مبتكر

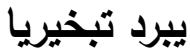

قدمت هذه الدراسة مكثقا تبخيريا مبتكرا لثلاجة منزليه.. أقرن المكثف المقترح كأحد مكونات دورة تبريد.. وتم اختبار هذه الدورة وتقييم كفاءتها.

المكثف عبارة عن سربنتينة من النحاس وضعت في قناة ذات مقطع مستطيل ولف علي أنابييها قطع رقيقه من القماش تدلت نهاياتها إلى أسفل لتمتص الماء من حوض سفلي وتبلل به الأنابيب بالخاصية

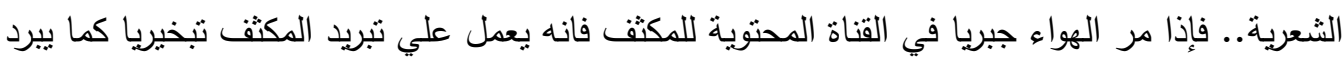

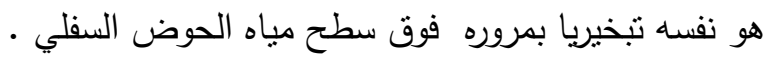

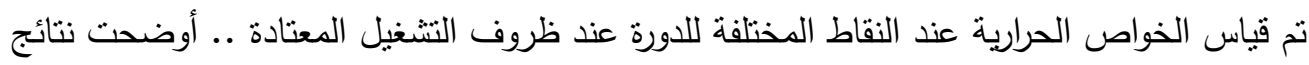
التجارب أن درجة حرارة المكثف تزداد 0.45 درجه مئوية لكل درجة واحده مئوية زيادة في المبخر ..

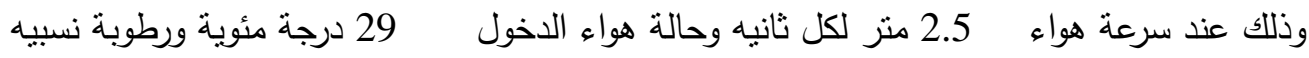
37.5\%..ومقابل ذلك نزداد درجة حرارة المكثق 0.88 درجه مئوية عند سرعة هواء 1.1 متر لكل ثانيه وحالة هواء الدخول 31 درجة مئوية ورطوبة نسبيه \% 47.1.

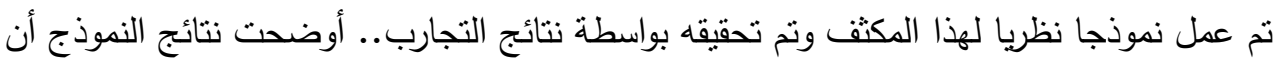
المكثف التبخيري ممكن أن يعمل عند درجة حرارة أقل 20 درجه مئوية عن منثله الذي ييرد بالهواء الجاف... وذلك عند فيض حراري 150 وات لكل متر مربع وسرعة هواء 3 متر لكل ثانيه.. تمت دراسة العوامل المختلفة التي تؤثر علي أداء المكثف نظريا. 